ÉGYPTE

monde arabe

\section{Égypte/Monde arabe}

$6 \mid 2003$

D'une intifâda l'autre. La Palestine au quotidien

\title{
«Les civils israéliens sont des assassins et des usurpateurs »
}

"Les coptes donnent leur bénédiction aux attentats suicide »Sawt alUmma, 8 avril 2002

\section{‘Abd al-Hafîz Sa'd}

\section{(2) OpenEdition}

\section{Journals}

Édition électronique

URL : https://journals.openedition.org/ema/946

DOI : $10.4000 /$ ema.946

ISSN : 2090-7273

Éditeur

CEDEJ - Centre d'études et de documentation économiques juridiques et sociales

Édition imprimée

Date de publication : 31 décembre 2003

Pagination : 155-156

ISBN : 2-87027-993-0

ISSN : $1110-5097$

Référence électronique

'Abd al-Hafîz Sa'd, « "Les civils israéliens sont des assassins et des usurpateurs » », Égypte/Monde arabe [En ligne], 6 | 2003, mis en ligne le 08 juillet 2008, consulté le 07 juillet 2022. URL : http:// journals.openedition.org/ema/946 ; DOI : https://doi.org/10.4000/ema.946

Ce document a été généré automatiquement le 7 juillet 2022.

Tous droits réservés 


\section{« Les civils israéliens sont des assassins et des usurpateurs »}

«Les coptes donnent leur bénédiction aux attentats suicide »Sawt alUmma, 8 avril 2002

\section{'Abd al-Hafîz Sa'd}

1 Les divergences de vue qui opposent les 'ulamâ' au sujet de la légitimité des opérations menées par les héros du peuple palestinien n'ont toujours pas trouvé de solution. Les uns condamnent ces opérations, les autres les considèrent comme des camaliyyât istishhâdiyya et chacun justifie sa position par des versets du Coran, par des traditions attestées.

2 Mais personne n'a prêté attention à l'avis des coptes sur la question bien qu'ils soient également concernés. Laissant de côté les fatwa du shaykh d'al-Azhar et du imâm de La Mecque, il était important de connaître l'avis des membres du clergé sur la question, dans la mesure où les meurtres et les destructions de Sharon n'ont épargné ni chrétiens ni musulmans, ni églises ni mosquées.

3 Anbâ Basantî, évêque de Hélouan [Hulwân] et de Ma‘sara, estime que les opérations suicide des Palestiniens sont exécutées par amour pour Dieu... et quoi de plus noble que de se donner la mort en sachant qu'on sacrifie sa vie pour les autres dans le but de libérer sa patrie ou de défendre sa cause... Le Palestinien qui agit de la sorte ne le fait pas pour semer la terreur, mais pour défendre un principe dont il est convaincu. Même les actions menées contre les civils ne sont ni des crimes, ni des suicides, car les Palestiniens ne peuvent rien contre les militaires armés jusqu'aux dents. Ajoutons à cela que tout Israélien est une cible militaire légitime du fait que son pays occupe des territoires palestiniens et qu'il accepte le gouvernement de Sharon. Dès lors que les Israéliens suivent un dirigeant arrogant, ils peuvent être considérés comme ses soldats et doivent s'attendre à subir les conséquences des injustices commises par leur dirigeant. Dans ce cas, le sacrifice de soi n'est pas un suicide. Le Christ ne s'est-il pas offert en sacrifice pour délivrer l'humanité ?

De son côté, le Père Morcos 'Azîz de l'église copte orthodoxe al-Mucallaqa commence l'entretien par une question à laquelle il répond lui-même : George Bush est-il chrétien 
et Sharon est-il juif ? Non, Bush n'est pas chrétien puisqu'il encourage le terrorisme de Sharon qui n'est pas juif mais sioniste. Or le sionisme n'est pas une religion et, par conséquent, il est inadmissible de qualifier de terroristes les actes entrepris par les Palestiniens ; les fidẩiyyîns sont des héros.

Pour le Père Salîb Matta Sâwîris, pasteur de l'église de la Vierge à Shubrâ, qui exprime le point de vue des ecclésiastes orthodoxes, les opérations suicide sont menées pour défendre une cause en se sacrifiant pour les autres. Celui qui défend sa patrie, son territoire et son honneur, accomplit un acte héroïque ; il meurt pour Dieu et pour la cause qu'il défend. L'histoire du christianisme regorge de récits sur les premiers martyrs, sur les supplices que leur ont fait subir les Romains et sur la force qui les animait et leur permettait de résister pour défendre leur foi. Les paroles de saint Trilinos prouvent bien que le sang des martyrs a été « la semence du christianisme ». Ce que font les Palestiniens ne peut donc pas être considéré comme un suicide ; même s'ils touchent des civils, ce sont des actes de légitime défense de la patrie, ajoute le Père Sâwîris, car les Palestiniens sont frustrés et désespérés et ne trouvent aucun autre moyen pour faire face à l'oppression et à l'injustice. Se faire exploser est le seul moyen laissé à leur portée et c'est là un héroïsme rare. Les qualifier de terroristes alors que ce sont des martyrs serait infâme. Le vrai terroriste qui mérite d'être exécuté sans pitié, c'est Sharon.

Anbâ Yûhannâ Qalta, assistant du patriarche copte catholique, qualifie quant à lui les opérations suicide en s'inspirant de l'ouvrage de Saint Augustin, La cité de Dieu (Madînat Allah) qui précise que toute guerre est un combat dans lequel tous les moyens sont à utiliser dans la mesure où c'est pour défendre sa patrie et sa foi. En partant de ce principe, les opérations menées par les Palestiniens sont des camaliyyât istishhâdiyya à cent pour cent. Ils ne font que défendre leur patrie. Anbâ Yûhannâ Qalta demande à Bush de lire l'Évangile et l'histoire du christianisme et de voir combien de martyrs sont morts pour défendre leur patrie et leur foi. Malheureusement, Bush n'a pas lu l'histoire. S'il avait parcouru l'Évangile, il aurait compris que ce sont les opérations suicide qui édifieront la Palestine.

7 Telle est la position des religieux catholiques et orthodoxes. L'avis des protestants n'est pas très différent. Ils estiment que ces opérations sont une réaction normale à ce que leur font subir les Israéliens. Il s'agit d'une légitime défense de soi, de leur patrie et de leurs terres. C'est une obligation religieuse. Ra'fat Zakî, pasteur de l'église anglicane des Pyramides, partage ce point de vue et ajoute que ces opérations doivent être sous le contrôle des dirigeants et des responsables et que, si elles sont motivées par une cause publique contre les colons qui usurpent les terres, elles constituent une obligation et doivent suivre les ordres du leader de manière à servir la stratégie générale. Tout ce que font les Palestiniens aujourd'hui relève du devoir sacré de libérer la patrie et n'est jamais en contradiction avec la religion. Ce ne sont pas des actes terroristes mais une arme de légitime défense. 
INDEX

Mots-clés : Palestine 